\title{
Medical consultation and communication with a family doctor from the patients' perspective - a review of the literature
}

\author{
LUDMIŁA MARCINOWICZ 1, A, в, D-F, STANISŁAW GÓRSKI 2, в, D, ,
}

${ }^{1}$ Department of Primary Health Care, Medical University of Bialystok

${ }^{2}$ Department of Medical Didactics, Jagiellonian University Medical College of Cracow

A - Study Design, B - Data Collection, C - Statistical Analysis, D - Data Interpretation, E - Manuscript Preparation,

$\mathbf{F}$ - Literature Search, $\mathbf{G}$ - Funds Collection

Summary The modern understanding of the quality of healthcare takes into account new roles that were granted to patients, including the possibility to assess healthcare based on their experience. A review of the literature shows that among the basic dimensions which serve to measure patients' satisfaction, issues related to communication are essential. The aim of the study is to determine the aspects of communication with a family doctor which are particularly important from the perspective of the patient. A review of the literature from the years 2000-2016 on communication with family doctors was performed, including articles based on both quantitative and qualitative studies. The main source of the data was the English-language online database PubMed, in which articles were searched for based on such key words as: "medical consultation", "family doctor", "general practitioner", "communication", "patient's perspective". Furthermore, information was searched for in Polish-language journals, books and textbooks for physicians, using a method of manual screening. Analysis of the literature allowed for the identification of the following aspects of communicating with a family doctor perceived by patients: the experience of patients, establishing rapport with a patient, listening, informing a patient, non-verbal behavior, use of a computer during a visit, communication issues from older patients' perspective, and the relationship between communication and dissatisfaction with care. In summary, the problems of communication between the patient and a family doctor are complex and diverse. The patients' perspective, with regard to expectations and satisfaction with various aspects of care, including communication, is an important indicator of the quality of care delivered by a family physician.

Key words: medical consultation, family doctor, communication.

Fam Med Prim Care Rev 2016; 18(3): 387-390

\section{Background}

Communication between a physician with a patient during a medical consultation is a complex process involving both verbal and nonverbal issues [1]. The purposes which a physician and a patient try to achieve using conversation include an increase in the accuracy and effectiveness of communication, improvement of the patient's health, and the promotion of cooperation and partnership [2].

The perspective of patients, including their expectations and satisfaction with various aspects of care, is an element of quality assurance [3] and constitutes a subject of scientific research [4-7]. A review of empirical works published in the years 2000-2013 demonstrates that among basic dimensions, in which the satisfaction of a patient with a medical visit is measured, issues related to communication, including ability of the doctor to listen, getting accurate and important information from the patient, providing explanations, providing information, and answering the questions and concerns of patients are important [4]. Inadequate communication between the patient and the doctor also has a negative impact on the adherence of patients to treatment recommendations $[8,9]$.

The modern understanding of the quality of healthcare takes into account new roles that were granted to patients, including the possibility to assess healthcare based on their experience [10]. An opinion poll conducted in north-eastern Poland among 570 patients of family doctors demonstrates that patients should assess the quality of healthcare; $84.2 \%$ of the respondents answered positively. The respondents jus- tified this by the fact that patients as taxpayers have this right and even obligation, and their opinion should be considered in order to improve healthcare. However, the respondents believed that the subject and scope of the assessment should mainly focus on the evaluation of the relationship between the patient and the physician [11].

The aim of the study is to determine the aspects of communication with a family doctor which are particularly important from the perspective of the patient. Based on the opinions and expectations of patients, recommendations related to the scope of the improvement of the communication skills of family doctors will be formulated.

\section{Methods}

A review of the literature on communication from the years 2000-2016 was performed, including articles based on both quantitative and qualitative studies. The main source of data was the English-language online database PubMed, in which the articles were searched for based on such key words as: "medical consultation", "family doctor", "general practitioner", "communication", "patient's perspective". Furthermore, information was searched for in Polish-language journals, books and textbooks for physicians, using a method of manual screening.

\section{Results}

Analysis of the literature allowed for the identification of the following aspects of communicating with a family doctor 
perceived by patients: the experience of patients, establishing rapport with a patient, listening, informing a patient, non-verbal behavior, use of a computer during a visit, communication issues from older patients' perspective, the relationship between communication and dissatisfaction with care.

\section{Experience of patients}

Rocque and Leanza performed a detailed analysis of 57 qualitative studies published in the years 1995-2015 concerning the experience of patients in communicating with a general practitioner. Using a meta-ethnographic method, they found that the experience of patients in the field of communication can be negative or positive, and concerns the results of communication. Negative experience is related to a lack of respect and disregard, time limitations, dominance of the biomedical approach to the patient during the visit, or concentration on the biological aspects of the disease, which makes discussing psychosocial determinants of the disease (e.g. emotions and impact of disease on life) difficult for the patients, and helplessness. Patients must share intimate information with a physician and undergo intimate procedures, and they feel uneasy and do not understand explanations and medical jargon. Positive experience was related to the skills concerning interpersonal relations. Patients appreciated doctors who listened attentively, and were empathetic and nonjudgmental; some subjects liked the use of humor and appropriate touching, e.g. shaking hands, technical skills (providing time for conversation with a patient and asking questions and informing), and an approach tailored to the needs of the patient, as well as the individualization of care (in the sense of an individual approach). Patients who had better experience in communication with their physician reported a better interpersonal relationship, higher quality of care, greater autonomy of the patient, adherence to treatment recommendations, and overall satisfaction with healthcare. The result of negative experience in communication was a lack of trust in the physician, worse assessment of healthcare quality, excessive use of services (too frequent use of the services of different family doctors for the same reason), as well as dissatisfaction of patients, frustration, depreciation (disapproval of the physician's approach) and less motivation to follow the physician's recommendations [12].

\section{Establishing rapport with a patient}

At the beginning of the visit it is important to establish contact with a patient, which consists of: greeting the patient, presentation and explanation of one's role (if people do not know one another, they meet for the first time), determining the patient's name and showing interest in the problem of the patient [2]. Greeting, e.g. by shaking hands with the patient, increases the satisfaction of the patient with the visit to a family doctor [6].

\section{Listening}

While gathering information about the patient and exploring his/her problems, it is important to listen to the answers of the patient without interrupting or directing the conversation, allow the patient to end the sentence on his/ her own, and provide enough time for reflection. Active listening also comprises verbally and nonverbally encouraging the patient to converse, and summarizing and paraphrasing the words of the patient [2]. From the perspective of the physician, listening plays three roles:

1) it allows the doctor to collect relevant data and make an accurate diagnosis, as well as select appropriate treatment;

2) it is a tool for creating, maintaining and strengthening a good physician-patient relationship;
3) it is a therapeutic means [13]. Attentive listening is an important element in the assessment of a medical visit, especially at the stage of identifying the reasons for the patient presenting for the visit and exploration of the patient's problems. Patients perceive active listening as an element favouring satisfaction with the care of a family doctor [14].

\section{Informing a patient}

An element of medical consultation is the correct amount and content of information provided to the patient. It is important to provide the patient with information in "small doses" and to check if the patient understands it [2]. Providing information, explanations and answers to questions is the second most common (the first is the effectiveness of treatment, accurate diagnosis, improvement of health condition and physical examination) category of patients' expectations from a family doctor determined based on survey research conducted in 30 family medicine centres in Poland [7]. The comprehensiveness of explanations provided to the patient during the visit is also an element of satisfaction with the family doctor [15].

\section{Non-verbal behavior}

The non-verbal way of communicating is an important element of the physician-patient relationship, and is a subject of the assessment of a visit to a family doctor from the patient's perspective. Silverman and Kinnersley report that patients are attentive observers of their physicians, and perceive many non-verbal signals on their part [16]. Qualitative research demonstrates that during the visit patients most often pay attention to the tone of voice of the family doctor and eye contact. Furthermore, they spontaneously perceive such non-verbal behaviors as: facial expression, touch, interpersonal space, the physician's clothing, gestures and body position. The appearance and equipment of the rooms, or waiting room, and the office of the family doctor are also important for them [17]. Other studies have shown that touch can be particularly useful and desirable in situations of suffering [18].

\section{Communication issues from older patients' perspective}

In the communication with elderly people it is very important to provide an adequate amount of time for consultation and consider possible problems with hearing, vision and memory [20]. A study of 200 oncology patients (mean age 75 years) in Israel demonstrates thata caring communication style, or showing compassion and care, is an important factor influencing the satisfaction of patients with the care of their family doctors [21]. The results of qualitative studies indicate that people aged 65 and above, during a visit to a family doctor, especially appreciate his/her socio-emotional behavior, or smiling, addressing to the patient using his/her name, the possibility of discussing topics other than disease, listening, interest in the patient's problem, support, kindness, and sense of humor [22].

\section{Relationship between communication and satisfaction with care}

Problems in communicating with a family doctor may be a reason for the dissatisfaction of patients with the care provided by a family doctor. It is related to factors such as lack of listening to the patient, lack of reaction to the emotions of the patient, lack of calming and cheering [23], lack of the possibility of asking the doctor questions, insufficient information about treatment, and barriers to nonverbal communication (lack of eye contact) [6]. 
Langewitz et al., based on their study, conclude that patients are a source of much information (medical, therapeutic, psychosocial and related to lifestyle), but only some of them are considered by physicians. Furthermore, physicians do not discuss this subject with their patients and do not ask whether the given information should be recorded in their documentation [24].

The present work is based on reliable scientific research, both qualitative and quantitative from the last several years. However, the literature review may not cover all publications describing the perspective of the patient related to communication with the family doctor, which is a limitation of the present study.

\section{Conclusions}

A review of the literature demonstrates that during the evaluation of a visit to a family doctor, patients perceive the following aspects of communication: establishing contact, including greeting, attentive listening by the physician, the manner of providing information, an empathetic attitude, the use of humor, and nonverbal behavior (mainly the tone of voice, eye contact and appropriate touching).

Considering the opinions and expectations of patients, family doctors should improve their communication skills, especially in the fields of:

- active listening to the patient,

- exploration of concerns related to the disease, and expectations of the patient related to the visit,

- $\quad$ providing information about the disease, treatment and procedure in a manner understandable to the patient, individually adjusting the information and considering possible limitations, e.g. related to age,

- identification of nonverbal behaviors of the patient and responding to them.

Source of funding: This work was funded by the authors' resources.

Conflict of interest: The authors declare no conflict of interests.

\section{References}

1. Pawlikowska T, Zhang W, Griffiths F, et. al. Verbal and non-verbal behavior of doctors and patients in primary care consultations - how this relates to patient enablement. Patient Educ Couns 2012; 86(1): 70-76.

2. Silverman J, Kurtz S, Draper J. Skills for communicating with patients. 2nd ed. Oxford, San Francisco: Radcliffe Publishing; 2005.

3. Donabedian A. An introduction to quality assurance in health care. Oxford, New York: Oxford University Press; 2003.

4. Boquiren VM, Hack TF, Beaver K, et. al. What do measures of patient satisfaction with the doctor tell us? Patient Educ Couns 2015; 98(12): 1465-1473.

5. Kurpas D, Szwamel K, Mroczek B. Quality of care for patients with chronic respiratory diseases: data for accreditation plan in Primary Health Care. Adv Exp Med Biol 2016; 910: 71-85, doi: 10.1007/5584_2015_203.

6. Marcinowicz L, Grębowski R. Ocena opieki lekarza rodzinnego w świetle badań jakościowych: poszukiwanie komponentów zadowolenia i niezadowolenia pacjentów. Fam Med Prim Care Rev 2008; 10(2): 173-179.

7. Marcinowicz L, Grębowski R, Fiedorczuk I, et al. Oczekiwania pacjentów związane z wizytą u lekarza rodzinnego: analiza treści i próba typologii. Fam Med Prim Care Rev 2010; 10(12): 30-35.

8. Kardas P, Lewek P, Matyjaszczyk M. Determinants of patient adherence: a review of systematic reviews. Front Pharmacol 2013; 4: 91.

9. Kardas P. Przyczyny nieprzestrzegania zaleceń terapeutycznych. In: Gaciong Z, Kardas P, eds. Nieprzestrzeganie zaleceń terapeutycznych. Od przyczyn do praktycznych rozwiązań. Warszawa: Naukowa Fundacja Polpharmy; 2015.

10. Coulter A. The Autonomous Patient. Ending paternalism in medical care. London: The Nuffield Trust; 2002: 66-77.

11. Marcinowicz L, Gugnowski Z, Strumiło J, et al. Czy pacjenci chcą oceniać jakość opieki zdrowotnej? Krótki sondaż wśród pacjentów. Fam Med Prim Care Rev 2015; 11(1): 28-32.

12. Rocque R, Leanza Y. A systematic review of patients' experiences in communicating with primary care physicians: intercultural encounters and a balance between vulnerability and integrity. PLoS ONE 2015; 10(10): e0139577, doi: 10.1371/journal. pone.0139577.

13. Jagosh J, Boudreau JD, Steinert $Y$, et al. The importance of physician listening from the patients' perspective: Enhancing diagnosis, healing, and the doctor-patient relationship. Patient Educ Couns 2011; 85(12): 369-374.

14. Marcinowicz L, Chlabicz S, Grebowski R. Understanding patient satisfaction with family doctor care. J Eval Clin Pract 2010; 16(4): 712-715.

15. Põlluste K, Kalda R, Lember M. Evaluation of primary Health Care Reform in Estonia from patients' perspective: acceptability and satisfaction. Croat Med J 2004; 45(5): 582-587.

16. Silverman J, Kinnersley P. Doctors' non-verbal behaviour in consultations: look at the patient before you look at the computer. Br J Gen Pract 2010; 60(571): 76-78.

17. Marcinowicz L, Konstantynowicz J, Godlewski C. Patients' perceptions of GP non-verbal communication: a qualitative study. BrJ Gen Pract 2010; 60(571): 83-87.

18. Cocksedge S, George B, Renwick S, et al. Touch in primary care consultations: qualitative investigation of doctors' and parents' perceptions. Br J Gen Pract 2013; doi: 10.3399/bjgp13X665251.

19. Sobral D, Rosenbaum M, Figueiredo-Braga M. Computer use in primary care and patient-physician communication. Patient Educ Couns 2015; 98(12): 1568-1576.

20. Robinson TE 2nd, White GL Jr, Houchins JC. Improving communication with older patients: tips from the literature. Fam Pract Manag 2006; 13(8): 73-78.

21. Finkelstein A, Carmel S, Bachner YG. Physicians' communication styles as correlates of elderly cancer patients' satisfaction with their doctors. Eur J Cancer Care 2015; doi: 10.1111/ecc.12399DOI: 10.1111/ecc.12399.

22. Marcinowicz L, Pawlikowska T, Oleszczyk M. What do older people value when they visit their general practice? A qualitative study. Eur J Ageing 2014; 11(4): 361-367.

23. Marcinowicz L, Górska A, Chlabicz S. Przyczyny niezadowolenia pacjentów z opieki lekarza rodzinnego w świetle badań ankietowych - analiza odpowiedzi na pytania otwarte. Prz Lek 2007; 64(9): 559-562.

24. Langewitz WA, Loeb Y, Nübling M, et al. From patient talk to physicians notes - comparing the content of medical interviews with medical records in a sample of outpatients in Internal Medicine. Patient Educ Couns 2009; 76(3): 336-340. 
Address for correspondence:

Ludmiła Marcinowicz, PhD, Assoc. Prof.

Zakład Podstawowej Opieki Zdrowotnej UM

ul. Mieszka I 4 B

15-054 Białystok

Polska

Tel.: +48 85 732-68-20

E-mail: ludmila.marcinowicz@umb.edu.pl

Received: 17.03.2016

Revised: 04.04.2016

Accepted: 14.04.2016 